\title{
Als ambtenaren in de spiegel kijken
}

\section{Een onderzoek naar de relatie tussen arbeidsmotivatie en narcisme ${ }^{*}$}

\author{
Jochem van Heek \& Taco Brandsen
}

\begin{abstract}
Om meer inzicht te krijgen in de motivatie voor de publieke zaak is in dit onderzoek gezocht naar een relatie tussen de karaktereigenschap narcisme en arbeidsmotivatie van ambtenaren. Dit kan leiden tot nieuwe inzichten in de wetenschappelijke discussie met betrekking tot de spanning tussen persoonlijke instrumentele belangen en het dienen van het publieke belang. Uit de resultaten van het onderzoek onder ambtenaren uit drie verschillende organisaties bleek dat een narcistische drang naar autoriteit en bewondering ertoe leidt dat ambtenaren zich sterker aangetrokken voelen tot beleid en politiek. Daarentegen zorgde een toename in narcisme voor minder compassie bij de ambtenaren. Hoewel de betekenis van deze verbanden niet moet worden overdreven, toont het wel aan dat de relatie tussen persoonlijke en ambtelijke motivatie complexer is dan soms wordt verondersteld. In een samenleving die steeds narcistischer wordt, kan het zinvol zijn hiermee rekening te houden in het personeelsbeleid.
\end{abstract}

'It is probably not an exaggeration to state that if individuals with significant narcissistic characteristics were stripped from the ranks of public figures, the ranks would be perilously thinned, for the upper levels of government and industry are filled with "successful narcissists".' - Jerrold M. Post (Post, 1993, p. 99)

\section{Inleiding}

De optredens van Macron, Trump en Wilders lijken bovenstaand citaat te bevestigen. Narcisme kenmerkt de persoonlijkheid van vele politiek leiders (Glad, 2002). Daartoe behoort het geloof in de eigen leiderschapskwaliteiten, de drang om te leiden en het idee anderen buitengewoon goed te kunnen beïnvloeden (Emmons, 1984).

Dit beperkt zich echter niet tot politici. Sommige onderzoeken lijken erop te wijzen dat narcisme in de gehele samenleving, vergeleken tussen verschillende generaties, gestaag toeneemt (Ettema \& Zondag, 2002; Twenge, Konrath, Foster, Campbell, \& Bushman, 2008). Logischerwijs zullen er daardoor in de loop der tijd ook meer ambtenaren met narcistische eigenschappen bij zijn gekomen.

* Drs. J.H. van Heek is IT Docent bij Calco. Prof. Dr. T. Brandsen is hoogleraar bestuurskunde aan de Radboud Universiteit Nijmegen. 
De vraag is wat dat betekent voor het openbaar bestuur. Theorieën over ambtelijke motivatie gaan veelal uit van een tegenovergesteld uitgangspunt, namelijk dat van de onbaatzuchtige ambtenaar. De meest gebruikte conceptualisatie van ambtelijke motivatie, genaamd Public Service Motivation (PSM), gaat ervan uit dat de motivatie om te werken voor publieke organisaties is gestoeld op betrokkenheid met het algemeen belang. In zijn oratie geeft Steijn (2006b) aan dat hij het idee heeft dat medewerkers die carrièredoelen nastreven, minder zouden presteren voor de organisatie dan medewerkers die de publieke zaak willen dienen. Een gedragskenmerk als narcisme staat dus theoretisch gezien tegenover PSM vanwege het egocentrische element, maar in de praktijk is dat nog niet onderzocht. Als uit onderzoek zou blijken dat narcisme juist samenhangt met een hoge mate van PSM, dan moeten we concluderen dat het concept PSM op zijn minst uitgebreid of herzien moet worden. Het zou ook enige twijfel creëren over de resultaten van onderzoek naar de relatie tussen PSM en werkprestaties. Veel van dit onderzoek steunt op uitspraken van ambtenaren over hun eigen prestaties (Naff \& Crum, 1999; Leisink \& Steijn, 2009). Wanneer sprake is van een vertekend zelfbeeld, zoals dat voor narcisten kan gelden, is het de vraag hoeveel de antwoorden van dergelijke respondenten waard zijn. Zo bleek uit onderzoek naar leiderschap een wezenlijk verschil tussen de percepties van managers en die van werknemers, dat mogelijk verklaard kon worden door zelfoverschatting van de managers (Jacobsen \& Bøgh Andersen, 2015).

Verder is onduidelijk wat de toename van narcisme onder ambtenaren praktisch zou betekenen. Het streven naar invloed op de samenleving kan tot positieve uitkomsten leiden, waarbij voor narcisten persoonlijk succes een essentieel onderliggend doel is (Maccoby, 2000). De relatie met motivatie voor de publieke zaak is niet eenduidig. Enerzijds zou de drang naar persoonlijk succes personen kunnen belemmeren om hun ego opzij te zetten voor een groter geheel. Anderzijds zou succes in dienstbaarheid aan het algemeen belang juist een instrument tot persoonlijk succes kunnen zijn en zou narcisme indirect kunnen bijdragen aan de goede zaak.

Er is dus alle aanleiding om de mogelijke relatie tussen narcisme en motivatie voor de publieke zaak nader te onderzoeken. Aan de hand van bestaande theorieën over narcisme en Public Service Motivation zal in dit artikel een beeld worden geschetst van een mogelijke onderlinge relatie en de effecten die verschillende controlevariabelen hierop kunnen hebben. Hierna worden de methoden uiteengezet waarmee dit kwantitatief wordt onderzocht bij drie Nederlandse publieke organisaties. De resultaten hiervan worden vervolgens geanalyseerd om ten slotte tot discussiepunten, conclusies en aanbevelingen te komen.

\section{Theoretische benadering}

Arbeidsmotivatie in de publieke sector

In verschillende onderzoeken naar arbeidsmotivatie van werknemers in de publieke sector is de aanname ontstaan dat zij worden gedreven door een andere vorm van motivatie dan werknemers in de private sector (Perry \& Porter, 1982; 
Perry \& Rainey, 1988; Steijn, 2006a; Van Raaij, Vinken, \& Van Dun, 2002). Deze veronderstelling ligt ook aan PSM ten grondslag. Het werd ontwikkeld als alternatief voor rationele-keuzetheorieën (bijvoorbeeld de bekende versie van Niskanen), die lang de visie op ambtelijke motivatie domineerden (Perry, 2000; Ritz 2016). Hierbij zagen ze drie vormen van motieven binnen PSM: rationele motieven, zoals willen bijdragen aan beleid en politiek met de verwachting daarmee als individu belangrijk te zijn voor de samenleving; normatieve motieven, zoals het publiek belang dienen; en affectieve motieven, zoals vaderlandsliefde (Perry \& Wise, 1990). In de literatuur wordt gesteld dat PSM onder andere kan leiden tot betrokkenheid bij de organisatie, hogere prestaties (Perry \& Wise, 1990; Naff \& Crum, 1999), arbeidstevredenheid, minder neiging tot het zoeken van een andere baan (Pandey \& Stazyk, 2008 in Perry \& Hondeghem, 2008) en de bereidheid tot extra inspanning (Steijn \& Leisink, 2009).

Vandenabeele (2007, p. 547) definieert PSM als 'the belief, values and attitudes that go beyond self-interest and organizational interest, that concerns the interest of a large political entity and that motivates individuals to act accordingly whenever appropriate'. Bijna logischerwijs lijkt hieruit voort te vloeien, dat financiële incentives minder belangrijk worden naarmate de PSM van werknemers hoger wordt (Perry \& Wise, 1990; Bright, 2005). Aan de andere kant zijn er verschillende onderzoeken waarin wordt gesteld dat extrinsieke beloningen zoals geld ook van belang zijn voor ambtenaren met een hoge mate van PSM en dat hier ook zeker rekening mee moet worden gehouden (Alonso \& Lewis, 2001; Wright, Moynihan, \& Pandey, 2012). Deze spanning tussen de oorspronkelijk veronderstelde intrinsieke motivatie en het belang van extrinsieke motivatie is een van de pijnpunten van het PSM-concept, waar nader onderzoek naar nodig is (Bozeman \& Xuhong, 2015). Dat maakt de koppeling aan narcisme, bij uitstek gekoppeld aan extrinsieke motivatie, des te zinvoller.

\section{Narcisme}

Sinds Freuds (1905) eerste poging tot uiteenzetting van het begrip 'Narzißmus' is het uitgegroeid tot een bekend concept. Kernberg introduceerde de Narcissistic Personality Disorder (NPD), die gekenmerkt wordt door onder andere een ongewoon niveau van zelfreferentie tijdens gesprekken, een sterke drang om geliefd te zijn, weinig empathie voor de gevoelens van anderen en een zeer overgewaardeerd zelfbeeld (Kernberg, 1967). Echter, narcisme hoeft niet per se pathologisch te zijn (Kohut, 1966; Raskin \& Hall, 1979; Miller, Gaughan, Pryor, Kamen, \& Campbell, 2009). Kohut suggereerde zelfs dat een gezonde (functionele) vorm van narcisme zorgt voor meer creativiteit en humor. Er zou pas sprake zijn van pathologisch narcisme wanneer een individu niet kan omgaan met het verschil tussen zijn geïdealiseerde zelfbeeld en zijn ware tekortkomingen (Kohut, 1966). De omschrijving van narcisme en NPD door de American Psychiatric Association (APA) (2013) vult dit aan door te onderkennen dat veel succesvolle individuen over persoonskenmerken beschikken die kunnen worden gezien als narcistisch. Er is alleen sprake van NPD als deze eigenschappen inflexibel, onaangepast en hardnekkig zijn en zorgen voor een behoorlijk beperkte functionaliteit of voor persoonlijk lijden. 
Figuur 1 Theoretische dimensies binnen narcisme en PSM

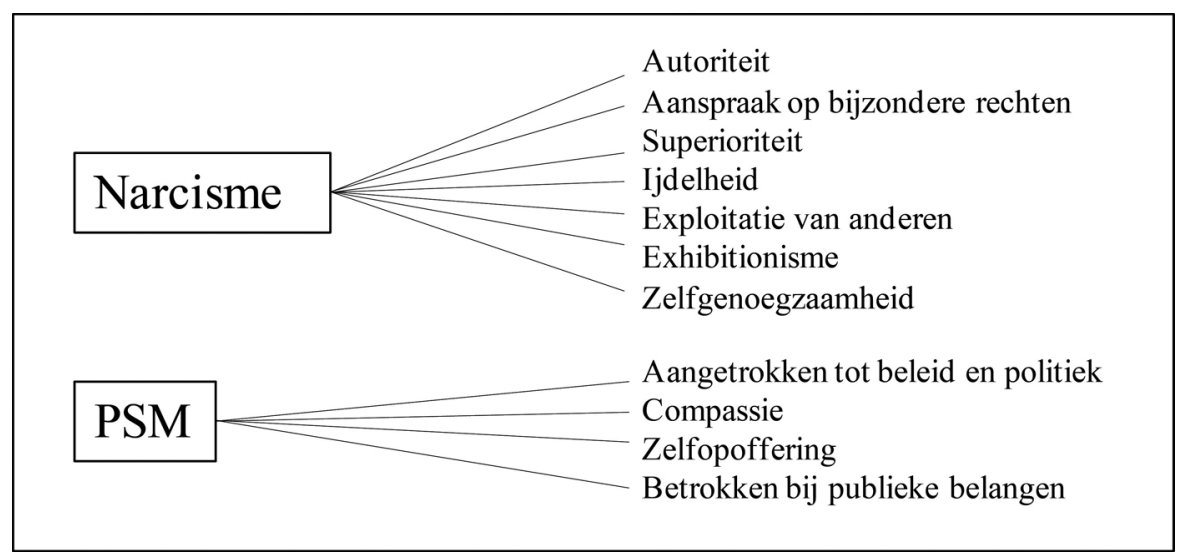

Het concept narcisme is in dit onderzoek voornamelijk geoperationaliseerd als overt narcisme, een zichtbare vorm van narcisme waarbij het individu naar buiten toe gericht is, in tegenstelling tot covert narcisme, waarbij het individu hypergevoelig, sociaal terughoudend en in zichzelf gekeerd is (Wink, 1991). Om aan het doel van dit onderzoek te voldoen is het van belang een vorm van narcisme te onderzoeken waarbij de zichtbaarheid groot is en de empathie laag (Wink, 1991), om hiermee de theoretische tegenstelling tegenover PSM te accentueren (vooral op de PSM-dimensie compassie). Tegelijkertijd is het wellicht mogelijk dat het gevoel van grandioosheid dat overt narcisme kenmerkt, een positief effect heeft op de drang om een impact op de samenleving te hebben. Bovendien wordt bij het meten van (overt) narcisme de NPI (Narcissistic Personality Inventory) van Raskin en Terry (1988) het meest gebruikt en wordt het breed geaccepteerd als 'standaardmeetinstrument' voor narcisme in psychologisch onderzoek (Cain, Pincus, \& Ansell, 2008; Brummelman, 2016).

\section{Theoretisch verband tussen narcisme en PSM}

Theoretisch gezien kan verondersteld worden dat het behalen van persoonlijke voordelen bij de narcistische aard past en dat narcisme dus geen positieve relatie met PSM heeft. Daarentegen zijn er aanwijzingen dat narcisme PSM in positieve zin kan versterken. Narcisme kan bijvoorbeeld een drijfveer zijn voor mensen om onderdeel te zijn van de politiek of het bedrijfsleven. Het is een positieve, constructieve vorm die leiders motiveert en gebaseerd is op zelfvertrouwen, identiteit en een duidelijk beeld van de eigen persoonlijkheid en capaciteiten (Kets de Vries, 1995). In dit onderzoek zijn narcisme en PSM opgebouwd volgens de dimensies die worden gebruikt door Raskin en Terry (1988) en Perry (1996), welke in figuur 1 zijn weergegeven.

Raskin en Terry (1988) onderscheiden verschillende dimensies van narcisme, die op verschillende wijze in gedrag naar voren kunnen komen en daarmee ook ver- 


\section{Figuur 2 De verwachte invloed van narcisme op PSM}

\section{Positieve invloed}

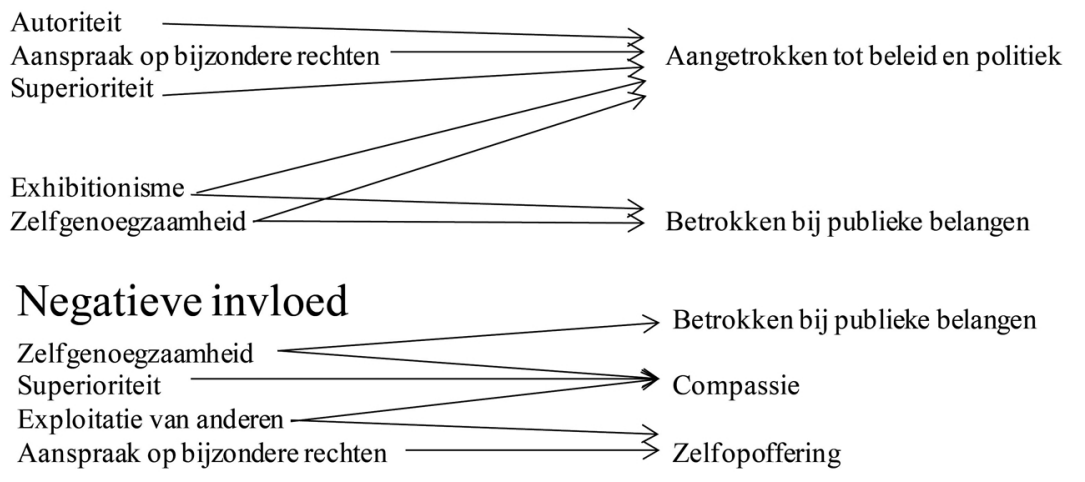

schillend van invloed kunnen zijn op de mate van PSM. Narcisten kunnen bijvoorbeeld van anderen verwachten dat zij voldoen aan hun verwachtingen en hen gebruiken om eigen doelen te bewerkstelligen (APA, 2013). Dit veronderstelt opoffering van anderen voor eigen belangen en een gebrek aan empathie, wat natuurlijk slecht aansluit bij PSM-dimensies als zelfopoffering en compassie. Verder trachten narcisten vaak hun zelfverzekerdheid te beschermen of te vergroten door te geloven dat ze beter zijn dan anderen in bepaalde vaardigheden. Een narcist zal sneller pronken met andermans veren, terwijl falen vaak wordt afgeschoven op anderen (Campbell, Reeder, Sedikides, \& Elliot, 2000). Dat kan leiden tot de behoefte om grandioos beleid voor een samenleving te willen maken, maar kan ten koste gaan van de sociale omgeving. Narcisten nemen ook eerder risico's dan anderen, vanuit de wil de wereld te veranderen en iets na te laten (Maccoby, 2000). Een zelfgenoegzame en exhibitionistische instelling kan ertoe leiden dat narcisten zich aangetrokken voelen tot beleid en politiek, en zo betrokken raken bij de publieke zaak. Dat zij niet wezenlijk geïnteresseerd zijn in het algemeen belang, sluit niet uit dat ze het nastreven om bewondering van anderen te verwerven.

Kortom, narcisme kan op verschillende manieren in gedrag naar voren komen en daarmee de mate van PSM bepalen. Op basis van literatuuronderzoek zijn in het onderzoek verschillende mogelijke verbanden tussen de dimensies van narcisme en PSM getest (zie figuur 2).

\section{Methoden en analyse}

\section{Dataverzameling}

In dit onderzoek is gebruikgemaakt van drie bestaande meetinstrumenten, die zijn samengevoegd in één survey. De survey is verhuld als 'vragen over een moge- 
lijk verband tussen inzet voor de publieke dienst en karaktereigenschappen', zodat respondenten zich in hun beantwoording niet zouden laten leiden door bijvoorbeeld sociale wenselijkheid of een persoonlijke aversie tegen narcisme. Om een omvattend beeld te krijgen van de relatie tussen narcisme en PSM zijn verschillende soorten Nederlandse ambtenaren bij drie verschillende organisaties benaderd voor dit onderzoek: een afdeling rijksambtenaren bij een nationaal agentschap; een kleine gemeente bestaande uit dorpen; en een grote gemeente. De survey is per e-mail verspreid onder ongeveer 150 rijksambtenaren van een nationaal agentschap, waarvan 69 respondenten gehoor gaven (46\%). Vervolgens is een survey verzonden naar ongeveer 200 ambtenaren bij een kleine gemeente, waarvan 39 reageerden (19,5\%). Ten slotte is een survey verspreid op het intranet (wat minder effectief was dan een directe e-mail) van een grote gemeente waar 1672 ambtenaren werkzaam waren en er 61 reageerden (3,6\%). Vanwege de lage respons in de grote gemeente is ervoor gekozen om in de analyse de resultaten niet uit te splitsen naar organisatie. Uiteindelijk is uitgegaan van $\mathrm{N}=169$, om op exploratieve wijze onder een gemêleerde groep van Nederlandse ambtenaren een eerste onderzoek te doen naar een mogelijk verband tussen narcisme en PSM.

Als meetinstrument voor de variabele narcisme is gekozen voor de NPI-16. Om respondenten die weinig tijd hebben beter te benaderen voor survey-onderzoek, hebben Ames, Rose en Anderson (2006) de NPI-16 ontwikkeld, welke gebaseerd is op de NPI-40 en vooral het begrip narcisme meet in plaats van alle dimensies hiervan. De NPI-16 meet alleen items die direct te maken hebben met het construct narcisme en niet met andere constructen zoals leiderschap of assertiviteit. In dit onderzoek werd een alpha van ,74 gemeten.

De variabele PSM is gemeten door gebruik te maken van de survey van Steijn en Leisink (2009). Hierbij ligt de nadruk op de dimensies aangetrokken zijn tot beleid en politiek, betrokkenheid bij het publieke belang en compassie. Deze survey heeft het voordeel vrij kort te zijn (10 items) en is bovendien aangepast op de Nederlandse context. Er is een Cronbachs alpha gemeten van ,65, wat betrekkelijk laag is, maar wat te verklaren is door de sterke inkorting van de vragen die PSM definiëren (van 40 naar 10).

Tot slot maakt de survey gebruik van een 5-punts Likertschaal en zijn vier van de tien items omgedraaid. Om aan te sluiten bij deze schaal is ervoor gekozen om narcisme (2-punts) en Big Five persoonlijkheid (7-punts) ook te bevragen met een 5-puntsschaal.

Bij het beantwoorden van de vraag of er sprake is van een verband tussen narcisme en PSM zijn in dit onderzoek vier controlevariabelen meegenomen die dit verband zouden kunnen beïnvloeden. Alle vier zijn ze eerder onderzocht met betrekking tot zowel narcisme als PSM, waardoor er bepaalde verwachtingen zijn over de mate van invloed van deze controlevariabelen. Het gaat hier om geslacht, leeftijd, organisatie en managementfunctie.

De enquêteresultaten zijn geanalyseerd door per steekproef eerst de constructen te controleren op validiteit en betrouwbaarheid. Vervolgens zijn interne dimensies gemeten met een factoranalyse en zijn (indien nodig) nieuwe dimensies opgesteld of items verwijderd. Vervolgens zijn regressieanalyses gedaan tussen de con- 
structen en onderlinge dimensies op basis van de theoretische verwachtingen. Tenslotte zijn de resultaten weergegeven en geïnterpreteerd.

\section{Constructanalyse}

De Big Five persoonlijkheidsdimensies, op aangenaamheid na, zouden positief moeten correleren met narcisme zodat geverifieerd kan worden of daadwerkelijk narcisme is gemeten (Ames et al., 2006). De resultaten van aangenaamheid, extraversie en openheid bevestigen de verwachte correlatie met narcisme. Dit versterkt het vermoeden dat narcisme daadwerkelijk is gemeten.

Voor narcisme en PSM verschilden de gemiddelde scores binnen geslacht en leeftijdsgroepen niet significant bij $\mathrm{p}<0,1$. Managers scoorden ook geen significant hoger gemiddelde dan mensen in andere functies. Overigens bleek ook geen significant verschil in gemiddelden aanwezig tussen de verschillende organisaties.

De respondenten scoorden gemiddeld een PSM-score van 3,45. Dit is iets lager dan het gemiddelde van 3,56, dat Steijn \& Leisink (2009) hebben gemeten in Nederland met dezelfde vragenlijst. De gemiddelde score voor narcisme was 2,71. Bij de originele NPI-16 was dit 0,35 (twee keuzemogelijkheden). Vanwege het grote verschil in keuzemogelijkheden is dit niet te vergelijken met de Likertschaal (vijf keuzemogelijkheden), die in dit onderzoek is gebruikt.

Om te onderzoeken of er een verschil is in de invloed van functie, leeftijd, geslacht of organisatie op de dimensies van narcisme, zijn per dimensie de gemiddelde scores vergeleken met gebruik van de Tukey's post hoc test. Hieruit bleek dat binnen leeftijd en organisatie geen significante verschillen aanwezig waren. Wel bleek een significant verschil aanwezig op de dimensie autoriteit. In vergelijking tot mensen met een uitvoerende functie scoorden degenen met een managementfunctie ,67 hoger (SD = ,17), en zij met een strategische functie ,33 hoger $(S D=, 12)$. Tot slot verschilden mannen en vrouwen alleen significant op hun mate van exhibitionisme, waarbij mannen ,28 (SD = ,15) hoger scoorden dan vrouwen.

Inspectie van normale waarschijnlijkheidsplots liet zien dat er sprake was van normale verdelingen. Bij alle significante relaties zijn diagrammen tussen gestandaardiseerde residuen en gestandaardiseerde voorspelde waarden geïnspecteerd en bleek dat er sprake was van homoscedasticiteit. Er was sprake van onafhankelijkheid van residuen, gemeten met gebruik van de Durbin-Watson test. Dit varieerde bij significante relaties tussen 1,771 en 2,029. In een aantal gevallen vielen één of meer extreme waarden op. Er is echter voor gekozen om deze te behouden. Tot slot was bij de multipele regressieanalyses geen sprake van multicollineariteit.

\section{Resultaten}

Het onderzoek laat zien dat narcisme leidt tot een hogere aantrekkingskracht van beleid en politiek bij de individuele ambtenaar, maar ook tot minder compassie. Dat komt op verschillende manieren tot uiting. 
Table 1 Gevonden relaties tussen de aanwezige narcisme-, Big Five- en PSMdimensies

\begin{tabular}{|c|c|c|c|c|c|c|c|c|}
\hline \multirow[t]{2}{*}{ Variabelen } & \multicolumn{2}{|l|}{ PSM } & \multicolumn{2}{|c|}{$\begin{array}{l}\text { Betrokken bij } \\
\text { publieke belan- } \\
\text { gen }\end{array}$} & \multicolumn{2}{|c|}{$\begin{array}{l}\text { Aangetrokken } \\
\text { tot beleid en } \\
\text { politiek }\end{array}$} & \multicolumn{2}{|c|}{ Compassie } \\
\hline & $\mathbf{R}^{2}$ & b & $\mathbf{R}^{2}$ & b & $\mathbf{R}^{2}$ & b & $\mathbf{R}^{2}$ & b \\
\hline Narcisme & & & & & $1,7 \%$ & ,202* & $1,8 \%$ &,$- 326 *$ \\
\hline Leeftijd (20-29) & & & & & & & $4,6 \%$ &, $400 *$ \\
\hline Leeftijd (60-69) & & & & & $4,2 \%$ & $-1,143 *$ & & \\
\hline Autoriteit & & & & & $3,3 \%$ & , I76* & & \\
\hline Geslacht (Man) & & & & & $6 \%$ &, 537 & & \\
\hline Functie (Manager) & & & & & $6,5 \%$ &,$- 696^{*}$ & & \\
\hline Exhibitionisme & & & & & $2,8 \%$ &, $162 *$ & & \\
\hline $\begin{array}{l}\text { Openheid (Big } \\
\text { Five) }\end{array}$ & $6,5 \%$ &, $\mid 18 I^{*}$ & $2,2 \%$ &, $150 *$ & & & & \\
\hline
\end{tabular}

* Significant bij $\mathrm{p}<0$, I. Lege cel = niet significant effect. Controlevariabelen zijn schuingedrukt.

Een autoritaire en/of exhibitionistische persoonlijkheid voelt zich sterker aangetrokken tot beleid en politiek. Dit effect is sterker bij mannen en medewerkers in de steekproef uit de kleine gemeente. Opmerkelijk is dat dit effect zwakker wordt wanneer iemand een managementfunctie heeft, terwijl deze groep gemiddeld het hoogst scoorde op autoriteit. Een mogelijke verklaring zou kunnen liggen bij de effecten van politiek op het werk van publieke managers. Als de discretionaire ruimte van publieke managers op hoger niveau in sterkere mate wordt beperkt door beleidsmakers, belangengroepen en collega's, zal de aantrekkingskracht van beleid en politiek mogelijk afnemen. Andere medewerkers die hoog scoren op autoriteit hebben hier minder last van, omdat ze in hun dagelijkse werkzaamheden minder politieke inperking van hun bewegingsruimte ervaren.

Interessant is ook het verband met leeftijd. Het valt op dat bij jongere ambtenaren sprake is van een positieve relatie tussen narcisme en compassie, terwijl bij oudere ambtenaren een negatieve relatie is tussen narcisme en de aantrekkingskracht van beleid en politiek. Het effect bij de jongeren zou verklaard kunnen worden door een bevinding van Desmarais en Gamassou (2014), waaruit blijkt dat compassie hoger is onder lagere ambtenaren omdat zij dichter bij de burger staan en lager bij hogere ambtenaren omdat zij met abstractere vormen van beleid werken. Dit klopt als we ervan uitgaan dat medewerkers onder de dertig lagere functies hebben dan hun oudere collega's. Hierbij zou bovendien de narcistische drang naar 'wereldverandering' en beïnvloeding van anderen worden gestimuleerd, doordat de ambtenaar direct resultaat ziet van zijn acties op het leven van anderen.

Dat de aantrekkingskracht van beleid en politiek daalt bij oudere narcistischere ambtenaren sluit aan bij de bevindingen van Moynihan en Pandey (2007), waaruit blijkt dat een langer werkverband bij de organisatie leidt tot een daling in PSM. Hoe langer ambtenaren in een organisatie actief zijn, hoe meer zij zicht zul- 
len krijgen op de beperkte effecten van hun werk binnen de organisatie, of op het werk van de organisatie als geheel, waardoor frustratie, teleurstelling en cynisme ontstaan (Romzek \& Hendricks, 1982). Van narcisten is bekend dat zij niet op hun plek zijn in starre organisaties waarin zij weinig impact kunnen hebben (Rosenthal \& Pittinksy, 2006).

\section{Conclusie}

Er kan voorzichtig worden geconcludeerd dat narcisme een rol kan spelen in de mate van PSM van een individu. De voorzichtigheid is nodig omdat veel verwachte relaties niet significant waren en narcisme nog geen $2 \%$ van de spreiding van PSM verklaarde. Dat neemt niet weg dat een persoonlijkheid gericht op eigenbelang (narcisme) zich sneller aangetrokken lijkt te voelen tot beleid en politiek. Het gevoel belangrijk te zijn en bewondering te verkrijgen sluit aan bij de rationele motieven achter PSM (Perry \& Wise, 1990). Dat er een positieve relatie bestaat tussen narcisme en de aantrekkingskracht van beleid en politiek, laat zien dat de achterliggende veronderstellingen van Perry en Wise op dit punt accuraat waren. De negatieve relatie tussen narcisme en compassie bevestigt ook de spanning tussen eigenbelang en publiek belang. Het roept wel de vraag op of eigenbelang daadwerkelijk zo losstaat van PSM als vaak wordt verondersteld. Als PSM deels gestoeld is op eigenbelang, dan zijn de verschillende soorten motieven verstrengeld en is de arbeidsmotivatie van ambtenaren complexer, en misschien minder uitzonderlijk, dan menige studie suggereert.

De gevonden relaties en de mogelijke verklaringen hiervoor zouden ook de betrekkelijk lage tevredenheid met de organisatie van rijks- en gemeenteambtenaren kunnen verklaren (Ministerie van Binnenlandse Zaken en Koninkrijksrelaties, 2017). Het gevoel weinig invloed te hebben en weinig aandacht te krijgen voor het persoonlijk welzijn kan te maken hebben met de frictie die oudere ambtenaren en managers voelen wanneer zij sterkere gevoelens van narcisme en een drang naar autoriteit hebben. Bovendien sluit het aan bij de stelling van Taylor (2013) dat tevredenheid daalt wanneer ambtenaren met een hoge PSM geen impact kunnen hebben op de samenleving. Inspelen op narcisme en PSM kan daarmee van belang zijn in deze situatie.

Vanwege de lagere werktevredenheid onder rijks- en gemeenteambtenaren staat voor de betrokken overheidslagen de opgave centraal om hun personeelsbeleid te verbeteren. Narcisme is een eigenschap die mogelijk verandert hoe (potentiële) ambtenaren zich tot hun werk verhouden. Uit het onderzoek komen twee aanbevelingen naar voren: ten eerste kan op een toename in de drang naar autoriteit en bewondering (exhibitionisme) worden ingespeeld door ambtenaren meer verantwoordelijkheden te geven en successen zichtbaar te waarderen en te belonen. Waar de ruimte voor financiële extra's ontbreekt, kan met aandacht en complimenten (interviews in personeelsmagazines, leiderschapsposities in informele initiatieven) al veel worden gewonnen. Vooral voor oudere ambtenaren zou meer aandacht moeten zijn, wanneer de teleurstelling intreedt. Juist omdat oudere werknemers het aan het eind van hun carrière belangrijk vinden om een blijvende 
bijdrage te leveren aan de samenleving (Leisink \& Steijn, 2009) loont het zich om meer verantwoordelijkheid te bieden, omdat dit het gevoel vergroot impact te hebben op de samenleving. Dat kan bijvoorbeeld door een systeem van wederzijds mentorschap te introduceren (Van der Wal, 2017). De mogelijkheid om ervaring over te brengen en de confrontatie met jeugdig enthousiasme kunnen louterend werken. Daarmee kan de tevredenheid onder medewerkers met een hoge PSMscore gewaarborgd worden (Taylor, 2013). Verder mag de negatieve relatie met compassie niet worden vergeten en zou bij de invulling van functies gelet mogen worden op de mate van narcisme bij kandidaten - zeker in het sociale domein. Aangezien er vaak geen ruimte is voor uitgebreide assessments, dient er op zijn minst gelet te worden op een diverse samenstelling van commissies, met verschillende typen persoonlijkheden. Mensen hebben immers de neiging zichzelf te selecteren, wat een risico is wanneer narcisten aan het roer staan.

\section{Literatuur}

Alonso, P., \& Lewis, G.B. (2001). Public service motivation and job performance: Evidence from the federal sector. American Review Of Public Administration, 31(4), 363-380.

American Psychiatric Association (APA). (2013). Diagnostic and statistical manual of mental disorders, fifth edition (DSM-V). Washington, DC: American Psychiatric Association.

Ames, D.R., Rose, P., \& Anderson, C.P. (2006). The NPI-16 as a short measure of narcissism. Journal of Research in Personality 40, 440-450.

Bozeman, B., \& Xuhong, S. (2015). Public service motivation concepts and theory: A critique. Public Administration Review, 75(5), 700-710.

Bright, L. (2005). Public employees with high levels of public service motivation. Review Of Public Personnel Administration, 25(2), 138-154.

Brummelman, E. (2016). Narcistische kinderen. De Psycholoog, 1, 10-19.

Cain, N.M., Pincus, A.L., \& Ansell, E.B. (2008). Narcissism at the crossroads: Phenotypic description of pathological narcissism across clinical theory, social/personality psychology, and psychiatric diagnosis. Clinical Psychology Review, 28, 638-656.

Campbell, W.K., Reeder, G.D., Sedikides, C., \& Elliot, A.J. (2000). Narcissism and comparative self-enhancement strategies. Journal of Research in Personality, 34(3), 329-347.

Desmarais, C., \& Gamassou, C.E. (2014). All motivated by public service? The links between hierarchical position and public service motivation. International Review of Administrative Sciences, 80(1), 131-150.

Emmons, R.A. (1984). Factor analysis and construct validity of the Narcissistic Personality Inventory. Journal of Personality Assessment, 48, 291-300.

Ettema, J.H.M., \& Zondag, H.J. (2002). De Nederlandse Narcisme Schaal (NNS): Psychodiagnostisch gereedschap. De Psycholoog, 37, 250-255.

Freud, S. (1905). Drei Abhandlungen zur Sexualtheorie, in Studienausgabe V (pp. 43-145). Frankfurt am Main: S. Fischer Verlag.

Glad, B. (2002). Why tyrants go too far: Malignant narcissism and absolute power. Political Psychology, 23, 1-37.

Jacobsen, C.B., \& Bøgh Andersen, L. (2015). is leadership in the eye of the beholder? A study of intended and perceived leadership practices and organizational performance. Public Administration Review, 75(6), 829-841.

Kernberg, O. (1967). Borderline Personality Organization. Journal of the American Psychoanalytic Association, 15(3), 641-685. 
Kets de Vries, M.F. (1995). Life and death in the executive fast lane: Essays on irrational organizations and their leaders. San Francisco: Jossey-Bass.

Kohut, H. (1966). Forms and transformations of narcissism. Journal of the American Psychoanalytic Association, 14(2), 243-272.

Leisink, P., \& Steijn, B. (2009). Public service motivation and job performance of public sector employees in the Netherlands. International Review of Administrative Sciences, 75(1), 35-52.

Maccoby, M. (2000). Narcissistic leaders: The incredible pros, the inevitable cons. Harvard Business Review, 69-77.

Miller, J.D., Gaughan, E.T., Pryor, L.R., Kamen, C., \& Campbell, W.K. (2009). Is research using the narcissistic personality inventory relevant for understanding narcissistic personality disorder? Journal of Research in Personality, 43, 482-488.

Ministerie van Binnenlandse Zaken en Koninkrijksrelaties. (2017). Kennisbank Openbaar Bestuur: Werkbeleving. Geraadpleegd op 19 maart 2017 via http:// kennisopenbaarbestuur.nl/thema/werkbeleving/

Moynihan, D.P., \& Pandey, S.K. (2007). The role of organizations in fostering PSM. Public Administration Review, 1, 40-53.

Naff, K.C., \& Crum, J. (1999). Working for America: does PSM make a difference? Review of Public Personnel Administration, 4, 5-16.

Niskanen, W.A. (1971). Bureaucracy and representative government. Chicago: Aldine Atherton.

Pandey, S.K., \& Stazyk, E.C. (2008). Antecedents and correlates of PSM. In J.L. Perry \& A. Hondeghem (Eds.), Motivation in public management: The call of public service (pp. 101-117). Oxford: Oxford University Press.

Perry, J.L., \& Porter, L.W. (1982). Factors affecting the context for motivation in public organizations. The Academy of Management Review, 7(1), 89-98.

Perry, J.L., \& Rainey, H.G. (1988). The public-private distinction in organization theory: A critique and research strategy. The Academy of Management Review, 13(2), 182-201.

Perry, J.L., \& Wise, L.R. (1990). The motivational bases of public service. Public Administration Review, 50(3), 367-373.

Perry, J.L. (1996). Measuring public service motivation: An assessment of construct reliability and validity. Journal of Public Administration Research and Theory, 1, 5-22.

Perry, J.L. (2000). Bringing society in: toward a theory of PSM. Journal of Public Administration Research and Theory, 2, 471-488.

Post, J.M. (1993). Current concepts of the narcissistic personality: Implications for political psychology. Political Psychology, 14, 99-121.

Raaij, W.F. van, Vinken, H., \& Dun, L.P.M. van (2002). Het imago van de Publieke Sector als Werkgever. Tilburg: OSA.

Raskin, R.N., \& Hall, C.S. (1979). A narcissistic personality inventory. Psychological Reports, 45 ,

590.

Raskin, R., \& Terry, H. (1988). A principal-components analysis of the Narcissistic Personality Inventory and further evidence of its construct validity. Journal of Personality and Social Psychology, 54(5), 890-902.

Ritz, A., Brewer, G.A., \& Neumann, O. (2016). Public service motivation: A systematic literature review and outlook. Public Administration Review, 76(3), 414-426.

Romzek, B., \& Hendricks, J.S. (1982). Organizational Commitment and Representative Bureaucracy: Can We Have It Both Ways? American Political Science Review, 76(1), 75-82. 
Rosenthal, S.A., \& Pittinsky, T.L. (2006). Narcissistic leadership. The Leadership Quarterly, $17,617-633$.

Steijn, B. (2006a). Over ambtenaren en hun arbeidsmotivatie. Bestuurswetenschappen, 6, 444-466.

Steijn, B. (2006b). Carrièrejager of dienaar van de publieke zaak: Over ambtenaren en hun motivatie [Oratie]. Geraadpleegd via http://repub.eur.nl/pub/8030/Oratie_Steijn_lpdf.pdf

Steijn, B., \& Leisink, P. (2009). Gemotiveerd voor de publieke zaak? Public Service Motivation in Nederland. Bestuurswetenschappen, 1, 10-28.

Taylor, J. (2013). Public service motivation, relational job design, and job satisfaction in local government. Public Administration, 92(4), 902-918.

Twenge, J.M., Konrath, S., Forster, J.D., Campbell, K.W., \& Bushman, B.J. (2008). Egos inflating over time: A cross-temporal meta-analysis of the Narcissistic Personality Inventory. Journal of Personality, 76(4), 875-901.

Vandenabeele W. (2007). Towards a theory of public service motivation: An institutional approach. Public Management Review, 4, 545-556.

Wal, Z. van der (2017). De overheidsmanager in de 21e eeuw. Oratie, Universiteit Leiden, 3 maart 2017.

Wink, P. (1991). Two faces of narcissism. Journal of Personality and Social Psychology, 61(4), 590-597.

Wright, B.E., Moynihan, D.P., \& Pandey, S.K. (2012). Pulling the levers: Transformational leadership, public service motivation, and mission valence. Public Administration Review,72(2), 206-215. 